\title{
Design, Synthesis and Cytotoxicity of Novel Podophyllotoxin Derivatives
}

\author{
Peng-Fei Yu, ${ }^{a, b}$ Hong Chen, ${ }^{b}$ Jing WAnG,${ }^{b}$ Chun-Xian He, ${ }^{a}$ Bo CAO, ${ }^{b}$ Min Li, ${ }^{b}$ Na YAnG, ${ }^{a}$ \\ Zhi-Yong LEI, ${ }^{b}$ and Mao-Sheng CHENG*,a \\ ${ }^{a}$ Key Lab of New Drugs Design and Discovery of Liaoning Province, School of Pharmaceutical Engineering, Shenyang \\ Pharmaceutical University; Shenyang 110016, China: and ${ }^{b}$ Staff Room of Pharmacognosy, Medical College of Chinese \\ People's Armed Police Forces; Tianjin 300162, China.
}

Received November 6, 2007; accepted March 11, 2008; published online March 12, 2008

\begin{abstract}
A series of novel podophyllotoxin derivatives were designed using association strategy and synthesized by coupling either podophyllotoxin (1) or $4 \beta$-amino podophyllotoxin (3) with substituted indol-3-yl-glyoxyl chlorides. Their structures were identified using spectroscopic techniques. These novel derivatives have been evaluated for cytotoxicity in vitro against four human cancer cell lines with comparison to the parent compounds 1,3 and indibulin (2). Some of the compounds $(7 \mathrm{a}, 7 \mathrm{c})$ showed comparable cytotoxicity to that of podophyllotoxin.
\end{abstract}

Key words podophyllotoxin; indibulin; cytotoxicity; multidrug resistance

During the course of cancer chemotherapy treatment, it has been found that prolonged treatment of carcinoma patients with certain anticancer medicines can result in an acquired resistance toward multiple drugs, which is known as multidrug resistance (MDR). ${ }^{1)}$ The mechanism of MDR is not well understood. Until now, it was known that MDR is often associated with the overexpression of P-glycoprotein (P-gp) and/or multidrug resistance protein 1 (MDR1), the overproduction of specific tubulin isotypes, ${ }^{2)}$ and the decreased expression of topoisomerases, ${ }^{3)}$ etc. The development of MDR is one of the major problems encountered in chemotherapy. Hence, the need to overcome MDR has fueled considerable interest in the development of novel antitumor agents with cytotoxicity against MDR cancer cell lines.

A variety of natural products, such as Taxanes and Vincas, have proven to be successful in the clinical treatment of cancers. A well known cytotoxic natural product, aryltetralin lignan podophyllotoxin (1), can exert antitumor activity by inhibiting tubulin through binding with part of its colchicine domain. Moreover, podophyllotoxin-derived antitumor agents can also inhibit human DNA topoisomerase II. ${ }^{4,5)}$ Extensive structure modifications have been carried out on podophyllotoxin to reduce its high toxicity, which makes it unsuitable for clinical use as an anticancer medicine. As shown in Fig. 1 , two less toxic semisynthetic podophyllotoxin analogues, etoposide and teniposide, have been used for the treatment of a broad spectrum of tumors. ${ }^{6,7)}$ In addition, some newly developed derivatives (e.g. NPF and GL-331) display a better pharmacology profile and are currently in clinical trials. ${ }^{8,9)}$ However, some intrinsic shortcomings, such as MDR and toxicity, make these natural products faulty for clinical cancer treatment, which has stimulated researchers to discover novel tubulin inhibitors.

Indibulin (D-24851, $N$-(pyridin-4-yl)-[1-(4-chlorobenzyl)indol-3-yl]-glyoxylamide, 2) is a synthetic small molecule tubulin inhibitor discovered by Baxter Oncology. This clinical candidate was identified based on its ability to destabilize microtubules in tumor cells, thus exerting antitumor activity. The binding site of indibulin does not overlap with the tubulin-binding sites of well-characterized microtubule-destabilizing agents, such as colchicine or vincristine, suggesting that it may bind to a novel domain of tubulin. Indibulin shows significant antitumor activity against a variety of tu- mors in vitro and in vivo. Furthermore, indibulin demonstrates efficacy toward MDR tumor cells and no systemic toxicity in the treatment of rat tumor models in vivo, which might be related to its unknown tubulin-binding mode. ${ }^{10)}$

It has been hypothesized that tubulin-targeting agents possessing a novel binding mode could be effective to MDR cell lines. ${ }^{11,12)}$ Both podophyllotoxin and indibulin are potent microtubulin inhibitors, but the tubulin-binding sites of the two compounds are different. This intrigues us and has prompted us to design hybrids of indibulin and podophyllotoxin with the aim of discovering novel tubulin inhibitors that can both overcome MDR and lower podophyllotoxin's toxicity by binding to a novel tubulin-binding domain. The novel podophyllotoxin derivatives based on indol-3-yl-glyoxyl substituents were generated by replacing the pyridin-4-yl-amino moiety of indibulin with the structure of podophyllotoxin (1) or $4 \beta$-amino podophyllotoxin (3), as illustrated in Chart 1 . Incorporating an indole structure could provide a field for structural modification, and various commercially available scaffolds could be exploited to manipulate the substituents on the indole ring. More significantly, the target compounds are expected to inhibit human DNA topoisomerase II, just as some other podophyllotoxin derivatives do.

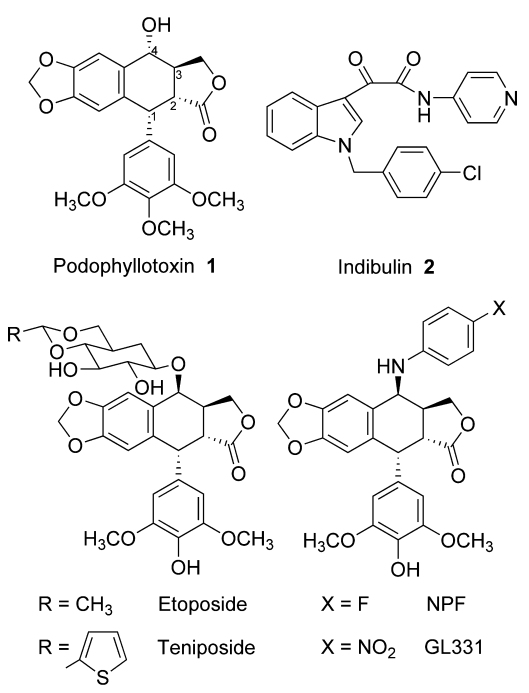

Fig. 1 

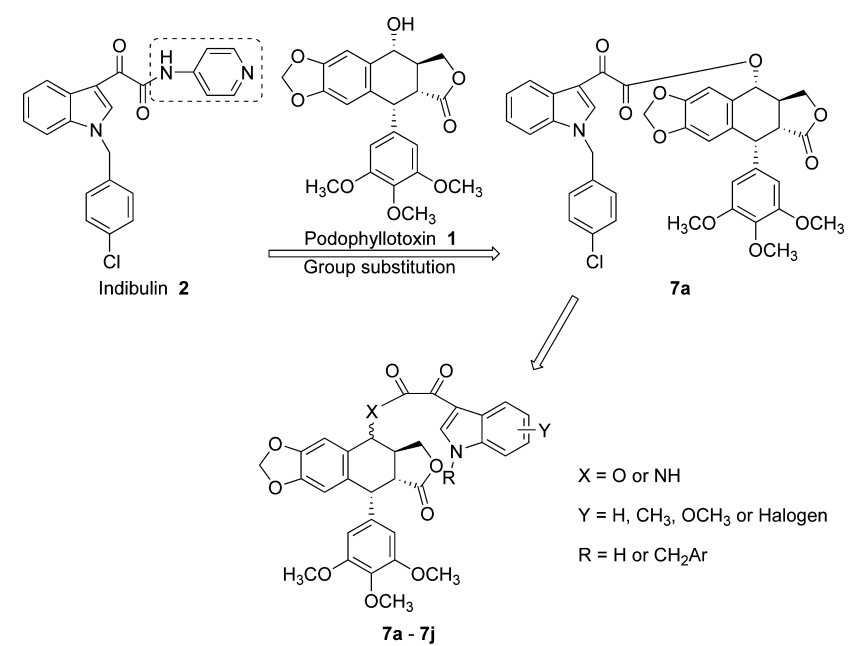

$\mathrm{X}=\mathrm{O}$ or $\mathrm{NH}$

$\mathrm{Y}=\mathrm{H}, \mathrm{CH}_{3}, \mathrm{OCH}_{3}$ or Halogen

$\mathrm{R}=\mathrm{H}$ or $\mathrm{CH}_{2} \mathrm{Ar}$

Chart 1. Design of the Novel Podophyllotoxin Derivatives
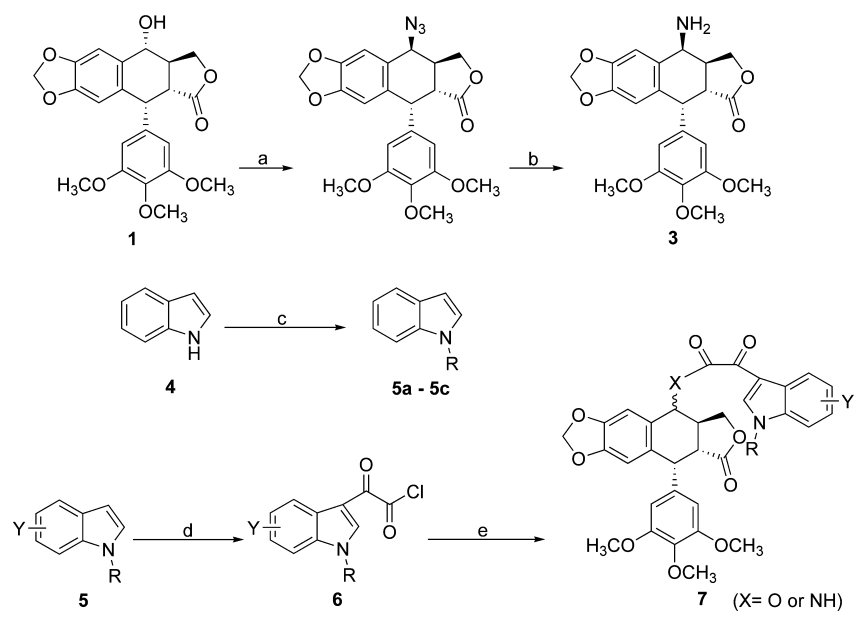

Reagents and conditions: (a) $\mathrm{NaN}_{3}, \mathrm{CF}_{3} \mathrm{COOH}, \mathrm{CHCl}_{3}$, reflux, $90 \%$; (b) $\mathrm{HCOONH}_{4}$, $\mathrm{CH}_{3} \mathrm{OH}$, rt, $70 \%$; (c) $\mathrm{NaH}, \mathrm{RX}, \mathrm{DMF}, 0{ }^{\circ} \mathrm{C}-\mathrm{rt}, 80-95 \%$; (d) oxalyl chloride, $\mathrm{Et}_{2} \mathrm{O}$, $0{ }^{\circ} \mathrm{C}, 70-95 \%$; (e) 1 or $3, \mathrm{Et}_{3} \mathrm{~N}, \mathrm{DMAP}, \mathrm{DMF}, 0{ }^{\circ} \mathrm{C}-\mathrm{rt}, 43-56 \%$.

Chart 2. Synthesis of Compounds $7 \mathbf{a}-\mathbf{j}$

We report herein the synthesis and cytotoxicity of a series of $4 \alpha-O$ - and $4 \beta-N$-indol-3-yl-glyoxyl-substituted derivatives of podophyllotoxin. The biological activity of these derivatives was evaluated by in vitro cytotoxicity study.

Chemistry The novel podophyllotoxin derivatives $7 \mathbf{a}-\mathbf{j}$ were prepared according to the general synthetic approach as depicted in Chart 2. The $N$-substituted indoles $\mathbf{5 a}-\mathbf{c}$ were readily synthesized by the reaction of indole 4 with an aralkyl chloride in the presence of $\mathrm{NaH}$. Treatment of substituted indoles 5 with oxalyl chloride in diethyl ether gave substituted indol-3-yl-glyoxyl chlorides 6 with a $70-95 \%$ yield. Subsequently, 6 was coupled with podophyllotoxin or $4 \beta$ amino podophyllotoxin in the presence of triethylamine and 4-( $N, N$-dimethylamino)-pyridine (DMAP) to generate the products listed in Table 1. As illustrated in Chart 2, $4 \beta$ amino podophyllotoxin was prepared from podophyllotoxin according to known procedures. ${ }^{5,13)}$ Acylation of podophyllotoxin retained the $\alpha$-configuration of its C- 4 carbon atom, which could be deduced from the ${ }^{1} \mathrm{H}-\mathrm{NMR}$ spectral data of $7 \mathbf{a}-\mathbf{c}$. In their ${ }^{1} \mathrm{H}-\mathrm{NMR}$ spectra, the $J$ value $(8.3 \mathrm{~Hz})$ of the hydrogen atom $(\delta 6.05$ or $6.06 \mathrm{ppm})$ at the $\mathrm{C}-4$ position of
Table 1. Structures of Synthesized Compounds

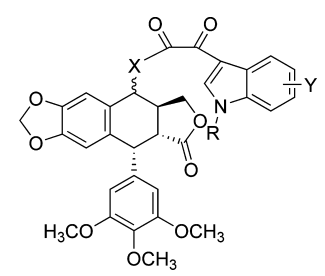

\begin{tabular}{ccccl}
\hline \hline Compound & C-4 configuration & $\mathrm{X}$ & $\mathrm{Y}$ & $\mathrm{R}$ \\
\hline $\mathbf{7 a}$ & $\alpha$ & $\mathrm{O}$ & $\mathrm{H}$ & 4-Chlorobenzyl \\
$\mathbf{7 b}$ & $\alpha$ & $\mathrm{O}$ & $\mathrm{H}$ & 3,4-Dichlorobenzyl \\
$\mathbf{7} \mathbf{c}$ & $\alpha$ & $\mathrm{O}$ & $\mathrm{H}$ & Benzo[1,3]dioxol-5-ylmethyl \\
$\mathbf{7 d}$ & $\beta$ & $\mathrm{NH}$ & $\mathrm{H}$ & 4-Chlorobenzyl \\
$\mathbf{7 e}$ & $\beta$ & $\mathrm{NH}$ & $\mathrm{H}$ & Benzo[1,3]dioxol-5-ylmethyl \\
$\mathbf{7 f}$ & $\beta$ & $\mathrm{NH}$ & 5-Bromo & $\mathrm{H}$ \\
$\mathbf{7 g}$ & $\beta$ & $\mathrm{NH}$ & 2-Methyl & $\mathrm{H}$ \\
$\mathbf{7 h}$ & $\beta$ & $\mathrm{NH}$ & 6-Fluoro & $\mathrm{H}$ \\
$\mathbf{7 i}$ & $\beta$ & $\mathrm{NH}$ & 5-Methoxy & $\mathrm{H}$ \\
$\mathbf{7} \mathbf{j}$ & $\beta$ & $\mathrm{NH}$ & 6-Methoxy & $\mathrm{H}$ \\
\hline
\end{tabular}

$7 \mathbf{a}-\mathbf{c}$ demonstrates their $4 \alpha$-configuration. The structures of the resulting compounds were identified by ${ }^{1} \mathrm{H}-\mathrm{NMR}$ and mass spectroscopy.

\section{Results and Discussion}

The biological activity of this series of podophyllotoxin derivatives was evaluated by an in vitro cytotoxicity test, which was carried out with a panel of four human cancer cell lines including HeLa (cervix), SKOV3 (ovary), K562 (leukemia) and K562ADR (adriamycin resistant leukemia), using podophyllotoxin (1), indibulin (2), $4 \beta$-aminopodophyllotoxin (3) and adriamycin as reference compounds. The screening procedure was based on the standard MTT or SRB method. The $\mathrm{IC}_{50}$ and $\mathrm{GI}_{50}$ values are shown in Table 2 .

As can be seen from the results, most of the derivatives presented substantial in vitro cytotoxic activity, even against the adriamycin resistant leukemia cell line (K562ADR). The potency of some of the compounds $(\mathbf{7 b}, 7 \mathbf{c}, 7 \mathbf{7}, 7 \mathbf{i}, 7 \mathbf{j})$ against K562ADR (the resistant multiple was 31.19) was comparable to those against the common K562 cell line. However, two derivatives $(7 \mathbf{g}, 7 \mathbf{h})$ were unable to inhibit the growth of K562ADR cells, though they displayed appreciable cytotoxicity against the three other common tumor cell lines.

In general, the $O$-linked derivatives (esters) of podophyllotoxin showed lower activity in comparison to the $N$-linked congeners (amides). However, as far as these analogues are concerned, the activities of ester derivatives are more potent than the amide derivatives (compare $\mathbf{7 a}$ with $\mathbf{7 d}$ and $\mathbf{7 c}$ with 7e), which might not only correlate with the hetero-atom at podophyllotoxin's C-4 position, but also with the configuration of the C-4 carbon atom.

Another finding was that a number of compounds exhibited improved cytotoxicity particularly with $N$-substituted group of the indole ring. Compound 7a was found to be more potent than $\mathbf{7 b}$, which was substituted by an additional chlorine atom at the $\mathrm{R}$ group compared with 7a. Compound 7c with benzo[1,3]dioxol-5-ylmethyl group substituted at position 1 of the indole ring is the most potent compound among all the synthetic derivatives against the four cancer cell lines. This compound inhibited the growth of K562ADR 
Table 2. The $\mathrm{IC}_{50}$ and the $\mathrm{GI}_{50}$ Values of the Novel Podophyllotoxin Derivatives

\begin{tabular}{|c|c|c|c|c|}
\hline \multirow{2}{*}{ Compound } & \multicolumn{2}{|c|}{$\mathrm{IC}_{50}(\mu \mathrm{M})$} & \multicolumn{2}{|c|}{$\mathrm{GI}_{50}(\mu \mathrm{M})$} \\
\hline & HeLa & SKOV3 & K562 & K562ADR \\
\hline $7 a$ & $0.55 \pm 0.06$ & $0.31 \pm 0.04$ & $0.03 \pm 0.01$ & $0.30 \pm 0.05$ \\
\hline $7 b$ & $0.65 \pm 0.08$ & $3.34 \pm 0.26$ & $0.10 \pm 0.02$ & $0.22 \pm 0.01$ \\
\hline $7 \mathrm{c}$ & $0.40 \pm 0.06$ & $0.24 \pm 0.03$ & $0.07 \pm 0.02$ & $0.18 \pm 0.02$ \\
\hline $7 d$ & $11.05 \pm 1.21$ & $13.49 \pm 1.17$ & $5.42 \pm 0.63$ & $7.61 \pm 0.68$ \\
\hline $7 e$ & $5.72 \pm 0.69$ & $9.50 \pm 1.08$ & $0.94 \pm 0.13$ & $33.85 \pm 2.76$ \\
\hline $7 f$ & $4.65 \pm 0.54$ & $46.20 \pm 4.13$ & $1.55 \pm 0.12$ & $1.51 \pm 0.19$ \\
\hline $7 \mathrm{~g}$ & $3.62 \pm 0.43$ & $7.96 \pm 0.88$ & $0.89 \pm 0.10$ & $>50$ \\
\hline $7 \mathrm{~h}$ & $1.34 \pm 0.12$ & $4.82 \pm 0.59$ & $1.95 \pm 0.16$ & $>50$ \\
\hline $7 \mathbf{i}$ & $0.94 \pm 0.10$ & $3.04 \pm 0.37$ & $0.21 \pm 0.02$ & $0.42 \pm 0.06$ \\
\hline $7 \mathbf{j}$ & $2.45 \pm 0.27$ & $7.85 \pm 0.64$ & $3.04 \pm 0.27$ & $3.09 \pm 0.28$ \\
\hline Podophyllotoxin & $0.10 \pm 0.02$ & $0.17 \pm 0.02$ & $0.03 \pm 0.01$ & $0.17 \pm 0.02$ \\
\hline $4 \beta$-Aminopodophyllotoxin & $1.27 \pm 0.14$ & $0.85 \pm 0.06$ & $0.36 \pm 0.03$ & $0.72 \pm 0.05$ \\
\hline Indibulin & $0.06 \pm 0.02$ & $0.30 \pm 0.04$ & $0.12 \pm 0.02$ & $0.28 \pm 0.02$ \\
\hline Adriamycin & - & - & $2.73 \pm 0.31$ & $85.15 \pm 8.07$ \\
\hline
\end{tabular}

a) Cytotoxicity against HeLa and SKOV3 cell lines was measured by the standard MTT assay method. b) Cytotoxicity against K562 and K562ADR cell lines was measured by the standard SRB assay method. c) Each value represents the mean \pm S.D. of three independent experiments.

carcinoma cells with a $\mathrm{GI}_{50}$ value of $0.18 \pm 0.02 \mu \mathrm{M}$, essentially comparable to those of podophyllotoxin and indibulin.

We also evaluated the effects of substitutents at other positions of the indole ring. Replacing the bromine atom of compound 7f with a lipophilic and electron-releasing methoxyl group in situ afforded derivative $\mathbf{7 i}$, resulting in an increased cytotoxicity by approximately one order of magnitude. Changing the position of the methoxyl group of compound $7 \mathbf{i}$ from C-5 to C- 6 of the indole ring conferred decreased cytotoxicity on isomer $\mathbf{7 j}$. The mechanism of action of these compounds will be further elucidated by biochemical investigations currently in progress.

In conclusion, a series of podophyllotoxin derivatives have been synthesized via a concise synthesis route and have been observed to act as novel cytotoxic agents against a series of four human cancer cell lines, including one that expresses the MDR phenotype. Therefore, the results obtained with the newly synthesized podophyllotoxin derivatives showed both that our association design strategy was applicable and that these derivatives are candidates worthy of additional research. Further studies are being conducted to determine the actions of these compounds on tubulin and human DNA topoisomerase II. Additional synthesis and in vivo antitumor activity studies are also currently in progress and will be reported in the near future.

\section{Experimental}

General All materials and reagents were obtained from commercial sources and used without further purification unless stated. Podophyllotoxin was purchased from the Huike Corporation of Shanxi province, China. $\mathrm{Et}_{2} \mathrm{O}$ was distilled from sodium-benzophenone. Melting points were determined on a BÜCHI Melting Point B-540 (Büchi Labortechnik) and were uncorrected. The ${ }^{1} \mathrm{H}-\mathrm{NMR}$ spectra were recorded using a BRUKER ARX-300 instrument at $300 \mathrm{MHz}$ spectrophotometer with tetramethylsilane (TMS) as the internal standard. The coupling constants $(J)$ are reported in Hz. Mass spectra data were obtained on a Quattro MicroTM API mass spectrometer (Waters, Milford, MA, U.S.A.) and a high resolution ESI-FTICR mass spectrometry (Ionspec 7.0T). Optical rotations were measured at room temperature with a Perkin-Elmer $241 \mathrm{MC}$ polarimeter at the sodium D line.

General Procedure for the Synthesis of 5a-c Indole $4(1.19 \mathrm{~g}$, $10.0 \mathrm{mmol}$ ) in anhydrous $5 \mathrm{ml}$ DMF was added slowly to a solution of $70 \%$ $\mathrm{NaH}(0.69 \mathrm{~g}, 20 \mathrm{mmol})$ in anhydrous $10 \mathrm{ml} \mathrm{DMF}$ at $0{ }^{\circ} \mathrm{C}$, and the mixture was subsequently stirred for $5 \mathrm{~h}$ at room temperature. The mixture was cooled to $0{ }^{\circ} \mathrm{C}$ and the aralkyl chloride $(12.0 \mathrm{mmol})$ was added to the mixture at one time. After $3-5 \mathrm{~h}$ stirring at room temperature, the mixture was added to $30 \mathrm{~g}$ ice water and stirred until precipitation. The product was filtered off, washed with water and dried under vacuum for $12 \mathrm{~h}$ at $25-30^{\circ} \mathrm{C}$. The title compounds $\mathbf{5 a}-\mathbf{c}$ were obtained respectively and could be used directly for the next step without further purification.

General Procedure for the Synthesis of $6 \mathrm{a}-\mathbf{c}$ and $6 \mathrm{f}-\mathbf{j}$ Substituted indole $5(5.0 \mathrm{mmol})$ was dissolved in $20 \mathrm{ml} \mathrm{Et} 2 \mathrm{O}$ and cooled to $0^{\circ} \mathrm{C}$. To this mixture, $0.58 \mathrm{ml}$ oxalyl chloride $(6.5 \mathrm{mmol})$ was then added drop wise with stirring so that the temperature did not rise above $5^{\circ} \mathrm{C}$. After an additional 3-6h stirring at room temperature, the resulting solid was filtered, washed with $10 \mathrm{ml} \mathrm{Et}{ }_{2} \mathrm{O}$ twice and dried under vacuum for $24 \mathrm{~h}$ at $25-30^{\circ} \mathrm{C}$. The title compounds $\mathbf{6} \mathbf{a}-\mathbf{c}$ and $\mathbf{6 f}-\mathbf{j}$ were obtained respectively and could be used directly for the next step without further purification.

General Procedure for the Synthesis of $7 \mathbf{a}-\mathbf{c} 0.42 \mathrm{~g}$ podophyllotoxin $1(1.0 \mathrm{mmol}), 0.28 \mathrm{ml} \mathrm{Et}_{3} \mathrm{~N}(2.0 \mathrm{mmol})$ and $5 \mathrm{mg}$ DMAP were dissolved in $5 \mathrm{ml}$ anhydrous DMF and cooled to $0{ }^{\circ} \mathrm{C}$. A solution of $6(2.0 \mathrm{mmol})$ in $15 \mathrm{ml}$ anhydrous DMF was added drop wise with stirring so that the temperature stayed below $5{ }^{\circ} \mathrm{C}$. The mixture was stirred at room temperature for $36 \mathrm{~h}$, and then extracted with dichloromethane $(40 \mathrm{ml} \times 3)$ after $30 \mathrm{ml}$ water was added. The organic phase was washed with water, dried over $\mathrm{Na}_{2} \mathrm{SO}_{4}$ and concentrated in vacuo. The residue was purified by column chromatography on silica gel using petroleum ether/ethyl acetate as eluent to produce $7 \mathbf{a}-\mathbf{c}$.

$4 \alpha$-((1-(4-Chlorobenzyl)-indol-3-yl)-glyoxyl)-podophyllotoxin (7a): Yield was found to be $51 \%$, mp $147.8^{\circ} \mathrm{C}(\mathrm{d})$. $[\alpha]_{\mathrm{D}}^{25}-69.0^{\circ}\left(c=0.10, \mathrm{CHCl}_{3}\right) .{ }^{1} \mathrm{H}-$ NMR $\left(\mathrm{CDCl}_{3}\right) \delta$ ppm: $2.99-3.02(2 \mathrm{H}, \mathrm{m}), 3.77(6 \mathrm{H}, \mathrm{s}), 3.81(3 \mathrm{H}, \mathrm{s}), 4.29$ $(1 \mathrm{H}, \mathrm{t}, J=9.5 \mathrm{~Hz}), 4.44-4.48(1 \mathrm{H}, \mathrm{m}), 4.65(1 \mathrm{H}, \mathrm{d}, J=3.6 \mathrm{~Hz}), 5.38(2 \mathrm{H}, \mathrm{s})$, $5.98(2 \mathrm{H}, \mathrm{d}, J=1.3 \mathrm{~Hz}), 6.06(1 \mathrm{H}, \mathrm{d}, J=8.3 \mathrm{~Hz}), 6.44(2 \mathrm{H}, \mathrm{s}), 6.58(1 \mathrm{H}, \mathrm{s})$, $6.89(1 \mathrm{H}, \mathrm{s}), 7.12(2 \mathrm{H}, \mathrm{d}, J=8.4 \mathrm{~Hz}), 7.30-7.39(5 \mathrm{H}, \mathrm{m}), 8.39(1 \mathrm{H}, \mathrm{s}), 8.44$ $(1 \mathrm{H}, \mathrm{d}, J=7.1 \mathrm{~Hz})$. ESI-MS $m / z$ : +ESI $732.2(\mathrm{M}+\mathrm{Na})$. HR-ESI-MS $m / z$ : 732.1597 (Calcd for $\mathrm{C}_{39} \mathrm{H}_{32} \mathrm{NO}_{10} \mathrm{ClNa}$ : 732.1612).

$4 \alpha$-((1-(3,4-Dichlorobenzyl)-indol-3-yl)-glyoxyl)-podophyllotoxin (7b): Yield was found to be $47 \%, \mathrm{mp} 116.8^{\circ} \mathrm{C}(\mathrm{d})$. $[\alpha]_{\mathrm{D}}^{25}-79.0^{\circ}(c=0.10$, $\left.\mathrm{CHCl}_{3}\right) .{ }^{1} \mathrm{H}-\mathrm{NMR}\left(\mathrm{CDCl}_{3}\right) \delta \mathrm{ppm}: 2.94-3.10(2 \mathrm{H}, \mathrm{m}), 3.77(6 \mathrm{H}, \mathrm{s}), 3.81$ $(3 \mathrm{H}, \mathrm{s}), 4.29(1 \mathrm{H}, \mathrm{t}, J=9.5 \mathrm{~Hz}), 4.45-4.51(1 \mathrm{H}, \mathrm{m}), 4.64(1 \mathrm{H}, \mathrm{d}, J=3.7 \mathrm{~Hz})$, $5.36(2 \mathrm{H}, \mathrm{s}), 5.98(2 \mathrm{H}, \mathrm{s}), 6.06(1 \mathrm{H}, \mathrm{d}, J=8.3 \mathrm{~Hz}), 6.44(2 \mathrm{H}, \mathrm{s}), 6.57(1 \mathrm{H}, \mathrm{s})$, $6.89(1 \mathrm{H}, \mathrm{s}), 6.98(1 \mathrm{H}, \mathrm{dd}, J=1.8,6.5 \mathrm{~Hz}), 7.27-7.43(5 \mathrm{H}, \mathrm{m}), 8.40(1 \mathrm{H}, \mathrm{s})$, $8.45(1 \mathrm{H}, \mathrm{d}, J=7.2 \mathrm{~Hz})$. ESI-MS $m / z$ : +ESI $766.1(\mathrm{M}+\mathrm{Na})$. HR-ESI-MS $m / z: 766.1215$ (Calcd for $\mathrm{C}_{39} \mathrm{H}_{31} \mathrm{NO}_{10} \mathrm{Cl}_{2} \mathrm{Na}$ : 766.1223).

$4 \alpha$-((1-(Benzo[1,3]dioxol-5-ylmethyl)-indol-3-yl)-glyoxyl)-podophyllotoxin $(7 \mathrm{c})$ : Yield was found to be $53 \%, \mathrm{mp} 110.3^{\circ} \mathrm{C}(\mathrm{d})$. $[\alpha]_{\mathrm{D}}^{25}-80.0^{\circ}$ $\left(c=0.10, \mathrm{CHCl}_{3}\right) .{ }^{1} \mathrm{H}-\mathrm{NMR}\left(\mathrm{CDCl}_{3}\right) \delta \mathrm{ppm}: 2.94-3.07(2 \mathrm{H}, \mathrm{m}), 3.76(6 \mathrm{H}$, s), $3.80(3 \mathrm{H}, \mathrm{s}), 4.27(1 \mathrm{H}, \mathrm{t}, J=9.5 \mathrm{~Hz}), 4.40-4.47(1 \mathrm{H}, \mathrm{m}), 4.64(1 \mathrm{H}, \mathrm{d}$, $J=3.7 \mathrm{~Hz}), 5.28(2 \mathrm{H}, \mathrm{s}), 5.94(2 \mathrm{H}, \mathrm{s}), 5.97(2 \mathrm{H}, \mathrm{d}, J=1.4 \mathrm{~Hz}), 6.05(1 \mathrm{H}, \mathrm{d}$, $J=8.3 \mathrm{~Hz}), 6.43(2 \mathrm{H}, \mathrm{s}), 6.56(1 \mathrm{H}, \mathrm{s}), 6.65(1 \mathrm{H}, \mathrm{s}), 6.69-6.78(2 \mathrm{H}, \mathrm{m}), 6.90$ $(1 \mathrm{H}, \mathrm{s}), 7.34-7.40(3 \mathrm{H}, \mathrm{m}), 8.30(1 \mathrm{H}, \mathrm{s}), 8.40-8.44(1 \mathrm{H}, \mathrm{m})$. ESI-MS $m / z:$ +ESI $742.2(\mathrm{M}+\mathrm{Na})$. HR-ESI-MS $m / z$ : 742.1891 (Calcd for $\mathrm{C}_{40} \mathrm{H}_{33} \mathrm{NO}_{12} \mathrm{Na}$ : 742.1900).

General Procedure for the Synthesis of $\mathbf{7 d}-\mathbf{j}$ The title compounds 
were synthesized by adopting the same procedure as for $7 \mathbf{a}-\mathbf{c}$ from $4 \beta$ amino podophyllotoxin 3

4 $\beta$-((1-(4-Chlorobenzyl)-indol-3-yl)-glyoxylamide)-4-desoxypodophyllotoxin (7d): Yield was found to be $56 \%, \mathrm{mp} 150.9^{\circ} \mathrm{C}(\mathrm{d}) .[\alpha]_{\mathrm{D}}^{25}-80.5^{\circ}$ $\left(c=0.10, \mathrm{CHCl}_{3}\right) .{ }^{1} \mathrm{H}-\mathrm{NMR}\left(\mathrm{CDCl}_{3}\right) \delta \mathrm{ppm}: 3.03-3.09(2 \mathrm{H}, \mathrm{m}), 3.73(6 \mathrm{H}$ s), $3.79(3 \mathrm{H}, \mathrm{s}), 3.88(1 \mathrm{H}, \mathrm{t}, J=9.7 \mathrm{~Hz}), 4.39-4.46(2 \mathrm{H}, \mathrm{m}), 5.24(1 \mathrm{H}, \mathrm{dd}$, $J=4.0,7.8 \mathrm{~Hz}), 5.38(2 \mathrm{H}, \mathrm{s}), 5.98(2 \mathrm{H}, \mathrm{s}), 6.19(1 \mathrm{H}, \mathrm{s}), 6.24(2 \mathrm{H}, \mathrm{s})$, $6.78(1 \mathrm{H}, \mathrm{s}), 7.15(2 \mathrm{H}, \mathrm{d}, J=8.3 \mathrm{~Hz}), 7.28-7.36(4 \mathrm{H}, \mathrm{m}), 7.42(1 \mathrm{H}, \mathrm{d}$, $J=7.8 \mathrm{~Hz}), 8.03(1 \mathrm{H}, \mathrm{d}, J=7.9 \mathrm{~Hz}), 8.39(1 \mathrm{H}, \mathrm{d}, J=7.8 \mathrm{~Hz}), 9.01(1 \mathrm{H}, \mathrm{s})$. ESI-MS $m / z$ : +ESI $731.2(\mathrm{M}+\mathrm{Na})$. HR-ESI-MS $m / z$ : 731.1765 (Calcd for $\left.\mathrm{C}_{39} \mathrm{H}_{33} \mathrm{~N}_{2} \mathrm{O}_{9} \mathrm{ClNa}: 731.1772\right)$.

$4 \beta$-((1-(Benzo[1,3]dioxol-5-ylmethyl)-indol-3-yl)-glyoxylamide)-4-desoxypodophyllotoxin (7e): Yield was found to be $58 \%, \mathrm{mp} 151.2{ }^{\circ} \mathrm{C}$ (d). $[\alpha]_{\mathrm{D}}^{25}-92.0^{\circ}\left(c=0.10, \mathrm{CHCl}_{3}\right) .{ }^{1} \mathrm{H}-\mathrm{NMR}\left(\mathrm{CDCl}_{3}\right) \delta \mathrm{ppm}: 3.01-3.08(2 \mathrm{H}$, $\mathrm{m}), 3.75(6 \mathrm{H}, \mathrm{s}), 3.81(3 \mathrm{H}, \mathrm{s}), 3.83-3.89(1 \mathrm{H}, \mathrm{m}), 4.41-4.47(1 \mathrm{H}, \mathrm{m}), 4.58$ $(1 \mathrm{H}, \mathrm{d}, J=3.6 \mathrm{~Hz}), 5.24(1 \mathrm{H}, \mathrm{dd}, J=3.6,8.0 \mathrm{~Hz}), 5.31(2 \mathrm{H}, \mathrm{s}), 5.91(2 \mathrm{H}, \mathrm{s})$, $5.98(2 \mathrm{H}, \mathrm{d}, J=4.6 \mathrm{~Hz}), 6.30(2 \mathrm{H}, \mathrm{s}), 6.45(1 \mathrm{H}, \mathrm{s}), 6.68(1 \mathrm{H}, \mathrm{s}), 6.72-6.80$ $(3 \mathrm{H}, \mathrm{m}), 7.31-7.40(3 \mathrm{H}, \mathrm{m}), 7.82(1 \mathrm{H}, \mathrm{d}, J=7.9 \mathrm{~Hz}), 8.39(1 \mathrm{H}, \mathrm{d}$, $J=7.1 \mathrm{~Hz}), 9.00(1 \mathrm{H}, \mathrm{s})$. ESI-MS $m / z$ : +ESI $741.2(\mathrm{M}+\mathrm{Na})$. HR-ESI-MS $m / z: 741.2048$ (Calcd for $\mathrm{C}_{40} \mathrm{H}_{34} \mathrm{~N}_{2} \mathrm{O}_{11} \mathrm{Na}$ : 741.2060).

$4 \beta$-((5-Bromo-indol-3-yl)-glyoxylamide)-4-desoxypodophyllotoxin (7f): Yield was found to be $43 \%$, mp $179.3^{\circ} \mathrm{C}(\mathrm{d})$. $[\alpha]_{\mathrm{D}}^{25}-91.5^{\circ}(c=0.10$, $\left.\mathrm{CHCl}_{3}\right)$. ${ }^{1} \mathrm{H}-\mathrm{NMR}\left(\mathrm{CDCl}_{3}\right) \delta$ ppm: $3.05-3.07(2 \mathrm{H}, \mathrm{m}), 3.75(6 \mathrm{H}, \mathrm{s}), 3.81$ $(3 \mathrm{H}, \mathrm{s}), 3.84-3.92(1 \mathrm{H}, \mathrm{m}), 4.43-4.48(1 \mathrm{H}, \mathrm{m}), 4.57(1 \mathrm{H}, \mathrm{d}, J=3.8 \mathrm{~Hz})$, $5.25(1 \mathrm{H}, \mathrm{d}, J=6.4 \mathrm{~Hz}), 5.98(2 \mathrm{H}, \mathrm{s}), 6.31(3 \mathrm{H}, \mathrm{s}), 6.77(1 \mathrm{H}, \mathrm{s}), 7.32(1 \mathrm{H}, \mathrm{d}$, $J=8.6 \mathrm{~Hz}), 7.42(1 \mathrm{H}, \mathrm{dd}, J=1.8,8.6 \mathrm{~Hz}), 7.87(2 \mathrm{H}, \mathrm{d}, J=7.7 \mathrm{~Hz}), 8.49(1 \mathrm{H}$, d, $J=1.4 \mathrm{~Hz}), 9.00(1 \mathrm{H}, \mathrm{d}, J=3.2 \mathrm{~Hz}), 9.63(1 \mathrm{H}, \mathrm{s})$. ESI-MS $m / z$ : + ESI $685.1\left(\mathrm{M}+\mathrm{Na}\right.$ ). HR-ESI-MS $m / z$ : 685.0790 (Calcd for $\mathrm{C}_{32} \mathrm{H}_{27} \mathrm{~N}_{2} \mathrm{O}_{9} \mathrm{BrNa}$ : $685.0798)$.

$4 \beta$-((2-Methyl-indol-3-yl)-glyoxylamide)-4-desoxypodophyllotoxin (7g): Yield was found to be $46 \%$, mp $175.1^{\circ} \mathrm{C}(\mathrm{d}) .[\alpha]_{\mathrm{D}}^{25}-105.5^{\circ}(c=0.10$, $\left.\mathrm{CHCl}_{3}\right) .{ }^{1} \mathrm{H}-\mathrm{NMR}\left(\mathrm{CDCl}_{3}\right) \delta \mathrm{ppm}: 2.76(3 \mathrm{H}, \mathrm{s}), 2.93-3.09(2 \mathrm{H}, \mathrm{m}), 3.76$ $(6 \mathrm{H}, \mathrm{s}), 3.82(3 \mathrm{H}, \mathrm{s}), 3.96(1 \mathrm{H}, \mathrm{t}, J=9.6 \mathrm{~Hz}), 4.45-4.52(1 \mathrm{H}, \mathrm{m}), 4.61(1 \mathrm{H}$, d, $J=4.0 \mathrm{~Hz}), 5.34(1 \mathrm{H}, \mathrm{dd}, J=4.3,7.7 \mathrm{~Hz}), 5.98(2 \mathrm{H}, \mathrm{d}, J=6.9 \mathrm{~Hz}), 6.32$ $(2 \mathrm{H}, \mathrm{s}), 6.54(1 \mathrm{H}, \mathrm{s}), 6.80(1 \mathrm{H}, \mathrm{s}), 7.20-7.33(4 \mathrm{H}, \mathrm{m}), 8.17(1 \mathrm{H}, \mathrm{d}$, $J=6.9 \mathrm{~Hz}), 8.75(1 \mathrm{H}, \mathrm{s})$. ESI-MS $m / z$ : +ESI $621.2(\mathrm{M}+\mathrm{Na})$. HR-ESI-MS $m / z$ : 621.1842 (Calcd for $\mathrm{C}_{33} \mathrm{H}_{30} \mathrm{~N}_{2} \mathrm{O}_{9} \mathrm{Na}: 621.1849$ ).

$4 \beta$-((6-Fluoro-indol-3-yl)-glyoxylamide)-4-desoxypodophyllotoxin (7h): Yield was found to be $48 \%, \mathrm{mp} 185.1^{\circ} \mathrm{C}(\mathrm{d}) .[\alpha]_{\mathrm{D}}^{25}-93.0^{\circ}(c=0.10$, $\left.\mathrm{CHCl}_{3}\right) .{ }^{1} \mathrm{H}-\mathrm{NMR}\left(\mathrm{CDCl}_{3}\right) \delta$ ppm: $3.02-3.06(2 \mathrm{H}, \mathrm{m}), 3.75(6 \mathrm{H}, \mathrm{s}), 3.82$ $(3 \mathrm{H}, \mathrm{s}), 3.86-3.92(1 \mathrm{H}, \mathrm{m}), 4.43-4.49(2 \mathrm{H}, \mathrm{m}), 5.26(1 \mathrm{H}, \mathrm{d}, J=6.7 \mathrm{~Hz})$, $5.98(2 \mathrm{H}, \mathrm{s}), 6.28(2 \mathrm{H}, \mathrm{s}), 6.34(1 \mathrm{H}, \mathrm{s}), 6.78(1 \mathrm{H}, \mathrm{s}), 7.09-7.17(2 \mathrm{H}, \mathrm{m})$, $7.84(1 \mathrm{H}, \mathrm{d}, J=7.8 \mathrm{~Hz}), 8.30(1 \mathrm{H}, \mathrm{dd}, J=5.5,8.1 \mathrm{~Hz}), 9.02(1 \mathrm{H}, \mathrm{d}$, $J=2.9 \mathrm{~Hz}), 9.35(1 \mathrm{H}, \mathrm{s})$. ESI-MS $m / z$ : +ESI $625.2(\mathrm{M}+\mathrm{Na})$. HR-ESI-MS $m / z$ : 625.1589 (Calcd for $\mathrm{C}_{32} \mathrm{H}_{27} \mathrm{~N}_{2} \mathrm{O}_{9} \mathrm{FNa}$ : 625.1598).

$4 \beta$-((5-Methoxy-indol-3-yl)-glyoxylamide)-4-desoxypodophyllotoxin (7i): Yield was found to be $45 \%, \operatorname{mp~} 174.6^{\circ} \mathrm{C}(\mathrm{d}) .[\alpha]_{\mathrm{D}}^{25}-100.5^{\circ}(c=0.10$, $\left.\mathrm{CHCl}_{3}\right) .{ }^{1} \mathrm{H}-\mathrm{NMR}\left(\mathrm{CDCl}_{3}\right) \delta \mathrm{ppm}: 2.95-3.09(2 \mathrm{H}, \mathrm{m}), 3.76(6 \mathrm{H}, \mathrm{s}), 3.82$ $(3 \mathrm{H}, \mathrm{s}), 3.84-3.92(1 \mathrm{H}, \mathrm{m}), 3.89(3 \mathrm{H}, \mathrm{s}), 4.43-4.49(1 \mathrm{H}, \mathrm{m}), 4.61(1 \mathrm{H}, \mathrm{d}$, $J=4.1 \mathrm{~Hz}), 5.26(1 \mathrm{H}, \mathrm{dd}, J=4.0,7.7 \mathrm{~Hz}), 5.98(2 \mathrm{H}, \mathrm{d}, J=4.4 \mathrm{~Hz}), 6.31(2 \mathrm{H}$, s), $6.48(1 \mathrm{H}, \mathrm{s}), 6.78(1 \mathrm{H}, \mathrm{s}), 6.97(1 \mathrm{H}, \mathrm{dd}, J=2.4,8.8 \mathrm{~Hz}), 7.35(1 \mathrm{H}, \mathrm{d}$, $J=8.8 \mathrm{~Hz}), 7.76(1 \mathrm{H}, \mathrm{d}, J=7.8 \mathrm{~Hz}), 7.88(1 \mathrm{H}, \mathrm{d}, J=2.3 \mathrm{~Hz}), 9.00(2 \mathrm{H}, \mathrm{s})$. ESI-MS $m / z$ : +ESI $637.2(\mathrm{M}+\mathrm{Na})$. HR-ESI-MS m/z: 637.1791 (Calcd for $\mathrm{C}_{33} \mathrm{H}_{30} \mathrm{~N}_{2} \mathrm{O}_{10} \mathrm{Na}$ : 637.1798).

$4 \beta$-((6-Methoxy-indol-3-yl)-glyoxylamide)-4-desoxypodophyllotoxin $(7 \mathbf{j})$ : Yield was found to be $50 \%, \operatorname{mp~} 170.2^{\circ} \mathrm{C}(\mathrm{d}) .[\alpha]_{\mathrm{D}}^{25}-102.5^{\circ}(c=0.10$, $\left.\mathrm{CHCl}_{3}\right) .{ }^{1} \mathrm{H}-\mathrm{NMR}\left(\mathrm{CDCl}_{3}\right) \delta \mathrm{ppm}: 3.03-3.07(2 \mathrm{H}, \mathrm{m}), 3.74(6 \mathrm{H}, \mathrm{s}), 3.81$ $(3 \mathrm{H}, \mathrm{s}), 3.86(3 \mathrm{H}, \mathrm{s}), 3.89-3.95(1 \mathrm{H}, \mathrm{m}), 4.39-4.47(2 \mathrm{H}, \mathrm{m}), 5.24(1 \mathrm{H}, \mathrm{d}$, $J=4.5 \mathrm{~Hz}), 5.97(2 \mathrm{H}, \mathrm{s}), 6.26(2 \mathrm{H}, \mathrm{s}), 6.77(1 \mathrm{H}, \mathrm{s}), 6.94(1 \mathrm{H}, \mathrm{s}), 7.03(1 \mathrm{H}, \mathrm{d}$, $J=8.7 \mathrm{~Hz}), 7.93(1 \mathrm{H}, \mathrm{d}, J=7.8 \mathrm{~Hz}), 8.22(1 \mathrm{H}, \mathrm{d}, J=8.8 \mathrm{~Hz}), 8.92(1 \mathrm{H}, \mathrm{d}$,
$J=2.9 \mathrm{~Hz}), 9.20(1 \mathrm{H}, \mathrm{s}), 9.40(1 \mathrm{H}, \mathrm{s})$. ESI-MS $m / z$ : +ESI $637.2(\mathrm{M}+\mathrm{Na})$. HR-ESI-MS m/z: 637.1787 (Calcd for $\mathrm{C}_{33} \mathrm{H}_{30} \mathrm{~N}_{2} \mathrm{O}_{10} \mathrm{Na}$ : 637.1798).

Cell Assay Cells were grown in RPMI-1640 medium supplemented with $10 \% \mathrm{FBS}, 100 \mathrm{U} / \mathrm{ml}$ penicillin and $100 \mu \mathrm{g} / \mathrm{ml}$ streptomycin and were incubated in a $5 \% \mathrm{CO}_{2}$ humidified atmosphere.

The cytotoxicity of compounds $7 \mathbf{a}-\mathbf{j}$ against HeLa and SKOV3 cell lines was evaluated by the MTT method in vitro. Cells were plated at a density of 4000 cells per well in a 96-well plate and incubated for $24 \mathrm{~h}$. The cells were then treated with increasing concentrations of tested compounds and grown for $4 \mathrm{~d}$. $100 \mu \mathrm{l}$ MTT (3-(4,5-dimethylthiazol)-2,5-diphenyltetrazolium bromide) at a concentration of $1.0 \mathrm{mg} / \mathrm{ml}$ in nutrient medium was added and cells were allowed to incubate for a further $4 \mathrm{~h}$. Then, $150 \mu \mathrm{l}$ DMSO was added to each well and the absorbance of samples were measured at $490 \mathrm{~nm}$. The $\mathrm{IC}_{50}$ values were calculated according to Logit method after getting the inhibitory rate.

The quantitative SRB (sulphorhodamine B) colorimetric assay was used to determine the cytotoxic effect of compounds $7 \mathbf{a}-\mathbf{j}$ on K562 and K562/ADR cell lines. Cells were seeded at 8000 per well in a 96-well plate and grown for $24 \mathrm{~h}$. After treating with increasing concentrations of tested compounds, cells were incubated for $4 \mathrm{~d}$. At the end of the incubation, cells were fixed with $80 \%$ trichloracetic acid $\left(1 \mathrm{~h}\right.$ at $\left.4{ }^{\circ} \mathrm{C}\right)$ and then stained for $30 \mathrm{~min}$ at room temperature with $100 \mu \mathrm{l} \mathrm{SRB}$ solution $(0.4 \% \mathrm{w} / \mathrm{v})$ in $1 \%$ acetic acid. SRB was then removed and cells were quickly rinsed five times with $1 \%$ acetic acid. After air-drying, protein-bound dye was dissolved in $150 \mu \mathrm{l}$ of $10 \mathrm{~mm}$ unbuffered Tris base $(\mathrm{pH} \mathrm{10.5)}$ for $5 \mathrm{~min}$. The pink SRB was quantified by measuring the optical density at $540 \mathrm{~nm}$. Then, values of $\mathrm{GI}_{50}$ were calculated.

Acknowledgements The authors gratefully thank the Great Program of Science Foundation of Tianjin (06YFJZJCO2700) and the Science Foundation of Chinese People's Armed Police Forces (WKH2005-6) for financial support of this research.

\section{References}

1) Kaye S. B., Curr. Opin. Oncol., 10 (Suppl. 1), S15-S19 (1998).

2) Ferlini C., Raspaglio G., Mozzeti S., Cicchillitti L., Fillippetti F., Gallo D., Fattorusso C., Campiani G., Scambia G., Cancer Res., 65, 23972405 (2005).

3) Wessel I., Jensen P., Falck J., Mirski S., Cole S., Sehested M., Cancer Res., 57, 4451—4454 (1997).

4) Lee K. H., Imakura Y., Haruna M., Beers S. A., Thurston L. S., Dai H. J., Chen C. H., Liu S. Y., Cheng Y. C., J. Nat. Prod., 52, 606-613 (1989).

5) Zhou X. M., Wang Z. Q., Chang J. Y., Chen H. X., Cheng Y. H., Lee K. H., J. Med. Chem., 34, 3346-3350 (1991).

6) Lee K. H., Beers S. A., Mori M., Wang Z., Kuo Y., Li L., Liu S., Cheng Y., Han F., Cheng Y., J. Med. Chem., 33, 1364-1368 (1990).

7) Wang Z., Kuo Y., Schnur D., Bowen J. P., Liu S., Hen F., Chang J., Cheng Y., Lee K. H., J. Med. Chem., 33, 2660-2666 (1990).

8) Tawa R., Takami M. J., Imakura Y. J., Lee K. H., Sakuri H., Bioorg. Med. Chem. Lett., 7, 489-494 (1997).

9) Xiao Z., Xiao Y. D., Golbraikh A., Tropsha A., Lee K. H., J. Med. Chem., 45, 2294-2309 (2002).

10) Bacher G., Nickel B., Emig P., Vanhoefer U., Seeber S., Shandra A., Klenner T., Beckers T., Cancer Res., 61, 392-399 (2001).

11) Dumontet C., Exp. Opin. Invest. Drugs, 9, 779-788 (2000).

12) Burkhart C. A., Kavallaris M., Horwitz S. B., Biochim. Biophys. Acta Rev. Cancer, 1471, O1-O9 (2001).

13) Chen S. Y., Yu Y. P., You J. Z., Chen Y. Z., Chem. J. Chin. Univ., 7, $1064-1066$ (2000). 